al. Automated laser fluorescence analysis of randomly amplified polymorphic DNA: a rapid method for investigating nosocomial transmission of Acinetobacter baumannii. J Med Microbiol 1995;43:446-451.

5. Matushek MG, Bonten MJM, Hayden MK. Rapid preparation of bacterial DNA for pulsed-field gel electrophoresis. J Clin Microbiol 1996;34:2598-2600.

6. Traub WH, Eiden A, Leonhard B, Bauer D. Typing of nosocomial strains of Serratia marcescens: comparison of restriction enzyme cleaved genomic DNA fragment (PFGE) analysis with bacteriocin typing, biochemical profiles and serotyping. Zentralblatt für Bakteriologie 1996;284:93-106.

7. Ariyasu RG, Nakamura T, Trousdale MD, Smith RE. Intraoperative bac- terial contamination of the aqueous humour. Ophthalmic Surgery 1993;24:367-373

8. Dhaliwal DK, Kowalski RP, Donahue SP, Doft BH, Karenchak LM. Evaluation of vitrectomy machines as a source of false-positive culture contamination in endophthalmitis. Am J Ophthalmol 1995;119:62-64.

9. de Courten C, Sancho P, BenEzra D. Metastatic Serratia marcescens endophthalmitis. J Pediatr Ophthalmol Strabismus 1988;25:45-47.

10. Joondeph HC, Nothnagel AF. Serratia rubidea endophthalmitis following penetrating ocular injury. Ann Ophthalmol 1983;15:1138-1140.

11. McCray E, Rampell N, Solomon SL, Bond WW, Martone WJ, O'Day D. Outbreak of Candida parapsilosis endophthalmitis after cataract extraction and intraocular lens implantation. J Clin Microbiol 1986;24:625-628.

\title{
Mechanically Ventilated Patients With MRSA Pneumonia
}

From 1990 to 1994 , Pujol and colleagues from the University of Barcelona, Spain, conducted a prospective cohort study to define the clinical and epidemiological characteristics of ventilator-associated methicillin-resistant Staphylococcus aureus (MRSA) pneumonia acquired during a large-scale outbreak of MRSA infection. Of 2,411 mechanically ventilated patients, 347 (14.4\%) acquired MRSA, 220 (63.4\%) had MRSA-positive respiratory tract samples, and 41 (18.6\%) developed ventilator-associated MRSA pneumonia. The overall attack rate for ventilatorassociated MRSA pneumonia was 1.56 episodes per 1,000 ventilator days, but annual attack rates varied according to the trend of the outbreak (range, 4.9-0.2).

In comparison with methicillinsensitive $S$ aureus (MSSA), which was implicated in 98 episodes of ventilatorassociated pneumonia, MRSA caused exclusively late-onset ventilator-associated pneumonia, while MSSA caused both early-onset (55 [56.1\%] of 98 episodes) and late-onset (43 [43.8\%] of 98 episodes) ventilator-associated pneumonia. Logistic regression analysis of all patients with $S$ aureus pneumonia revealed intubation for more than 3 days (odds ratio [OR], 1.11; $\mathrm{CI}_{95}, 1.03-1.18$ ) and prior bronchoscopy (OR, $5.8 ; \mathrm{CI}_{95}, 1.85-18.19$ ) to be independent variables associated with MRSA pneumonia.

The results indicate that MRSA ventilator-associated pneumonia is a frequent complication in intensivecare patients, manifesting itself as late-onset pneumonia in patients who have been intubated for prolonged periods or have undergone previous bronchoscopy.

FROM: Pujol M, Corbella X, Pena C, Pallares R, Dorca J, Verdaguer R, et al. Clinical and epidemiological findings in mechanically-ventilated patients with methicillinresistant Staphylococcus aureus pneumonia. Eur J Clin Microbiol Infect Dis 1998;17:622-628.

\section{Risk of Local Reactions Associated With Pneumococcal Re-vaccination}

\section{Gina Pugliese, RN, MS Martin S. Favero, PhD}

Re-vaccination of healthy adults with pneumococcal polysaccharide vaccine (PPV) within several years of first vaccination has been associated with a higher-than-expected frequency and severity of local injection-site reactions. The risk of adverse events associated with re-vaccination of elderly and chronically ill persons 5 or more years after first vaccination, as is recommended currently, has not been well defined. Jackson and colleagues conducted a comparative intervention study to determine whether revaccination with PPV at least 5 years after first vaccination is associated with more frequent or more serious adverse events than those following first vaccination.

The study period was April 1996 to August 1997 and included persons aged 50 to 74 years who had never been vaccinated with PPV $(n=901)$ or who had been vaccinated once at least 5 years prior to enrollment $(n=513)$.

Those who were re-vaccinated were more likely than those who received their first vaccinations to report a local injection-site reaction of at least $10.2 \mathrm{~cm}$ (4 in) in diameter within 2 days of vaccination: 11\% (55/513) vs $3 \%$ (29/901; relative risk [RR], 3.3; $\left.\mathrm{CI}_{95}, 2.1-5.1\right)$. These reactions resolved by a median of 3 days following vaccination. The highest rate was among re-vaccinated patients who were immunocompetent and did not have chronic illness: $15 \%(33 / 228)$ compared with $3 \%(10 / 337)$ among comparable patients receiving their first vaccinations $\left(\mathrm{RR}, 4.9 ; \mathrm{CI}_{95}, 2.4-\right.$ 9.7). The risk of these local reactions was significantly correlated with prevaccination geometric mean antibody concentrations.

The researchers note that physicians and patients should be aware that self-limited local injection-site reactions occur more frequently following re-vaccination compared with first vaccination; however, this does not represent a contraindication to revaccination with PPV for recommended groups.

FROM: Jackson IA, Benson P, Sneller VP, Butler JC, Thompson RS, Chen RT, et al. Safety of revaccination with pneumococcal polysaccharide vaccine. JAMA 1999;281:243-248. 